\title{
THE INFLUENCE OF METABOLIC SYNDROME ON THE QUALITY OF LIFE IN PATIENTS WITH ACUTE MYOCARDIAL INFARCTION WITH ST SEGMENT ELEVATION
}

\author{
Milan Lović1, Dragan Djordjević1, ${ }^{1,}$, Ivan S. Tasić1,2
}

\begin{abstract}
Metabolic syndrome (MetS) is a cluster of several risk factors that may indicate worse outcome after myocardial infarction with ST segment elevation (STEMI). The aim of this study was to determine the impact of MetS on quality of life among patients with STEMI.

A prospective study was performed among all STEMI patients who were treated with primary percutaneous coronary intervention in Clinical Centre of Serbia. During the three-year follow up, the occurrence of new cardiovascular events was followed. After 36 months the valid data were collected for 507 patients. At the end of the follow up, all alive and capable patients completed the Short Form 36 (SF-36) questionnaire.

The prevalence of MetS was $42.80 \%$. An increased appearance of new myocardial infarction $(p=0.004)$, new unexpected revascularizations $(p=0.014)$ and the increased number of hospitalizations because of heart failure $(p=0.050)$ were recorded in the group of patients with MetS during a follow-up. Multiple regression analysis revealed that MetS was a predictor for lower scores of: physical functioning (OR 2.684; $p<0.001$ ), role physical functioning (OR 2.121; $\mathrm{p}=0.001$ ), bodily pain (OR 2.559; $\mathrm{p}=0.005)$, general health (OR 2.522; $\mathrm{p}<0.001$ ) and physical component score (OR 2.516; $\mathrm{p}<0.001)$. Among mental components, MetS was a predictor of lower scores of vitality (OR 1.999; $p=0.002)$ and mental health (OR 2.142; $p=0.016)$.

Patients with MetS are at high risk for the appearance of new cardiovascular events, and the presence of this syndrome is associated with poorer quality of life after surviving STEMI.
\end{abstract}

Acta Medica Medianae 2018;57(4):71-78.

Key words: metabolic syndrome; myocardial infarction with ST segment elevation; quality of life; new cardiovascular events

${ }^{1}$ Institute for prevention and cardiovascular rehabilitation

"Niška Banja", Serbia

2University of Niš, Faculty of Medicine, Niš, Serbia

Contact: Milan Lović

Srpskih junaka 7, 18205 Niška Banja, Serbia

E-mail: milan.lovic@gmail.com

\section{Introduction}

Metabolic syndrome (MetS) is defined as a group of interrelated factors that significantly increase the risk of coronary artery disease, other forms of atherosclerotic cardiovascular disease, type 2 diabetes mellitus, cardiovascular mortality, and all-cause mortality. These factors are: hypertrigliceridemia, low level of HDL cholesterol, hypertension, abdominal obesity and insulin resistance $(1,2)$.
Myocardial infarction with ST-elevation (STEMI) remains to be a significant cause of morbidity and mortality throughout the world among CVD $(3,4)$. Conventional treatment focuses mainly on functional outcomes, survival and extending life. However, morbidity and mortality rates are incomplete measures of outcome, since they do not reflect all aspects of health. Many patients consider the quality of the additional life years gained equally important as the length of life. Indeed, the goal of today's medicine should be to increase both patients' quantity and quality of life (5). In response, assessment of healthrelated quality of life (HRQoL) has been increasingly integrated in daily clinical practice. HRQoL is a subjective measure of overall well-being and reflects how a disease and its symptoms are perceived by a patient. Although there is no universal agreement on what constitutes HRQoL, current assessment focuses on the domains of social functioning, physical functioning and psychological functioning (6). It is known that acute cardiovascular events, such as myocardial infarction and stroke, influence on the HRQoL. MetS is a chronic, progressive and multi-complex health 
problem that can trigger physical, emotional and psychosocial problems. The impact of MetS on healthrelated quality of life is yet to be clearly established, although obesity, diabetes and hypertension have obvious consequences of HRQoL $(7,8)$. However, little is known about how MetS influences the appearance of new cardiovascular events and HRQoL in patients with STEMI treated with primary percutaneous coronary intervention (pPCI). Therefore, our objective was to estimate the influence of MetS to new cardiovascular events and HRQOL among patients with STEMI.

\section{Material and methods}

This prospective study included 507 consecutive patients having suffered acute STEMI and treated with primary percutaneous coronary intervention (pPCI) in Clinical Center of Serbia, Belgrade Serbia, between December 2009 and June 2010. The diagnosis of STEMI was established and pPCI performed using guidelines for the management of acute myocardial infarction in patients presenting with STsegment elevation of European Society of Cardiology (9). In brief, patients with an episode of chest pain within the last 12 hours and ST-elevation on electrocardiography (ECG) in at least two consecutive leads were included.

After pPCI patients were hospitalized in the Cardiology Department with continuous monitoring including clinical, ECG, laboratory and echocardiography. Echocardiography was performed in the first week of myocardial infarction, on the ultrasonic unit Vivid 4 according to the clinical standard and in accordance with recommendations related to current echocardiography guidelines (10).

\section{Diagnosing of metabolic syndrome}

To set up the diagnosis of MetS we used AHA /NHLBI (American Heart Association and the National Heart, Lung and Blood Institute) criteria: central obesity, waist circumference $102 / 88 \mathrm{~cm}(\mathrm{M} / \mathrm{F})$; tryglycerides $\geq 1.7 \mathrm{mmol} / \mathrm{L} ; \mathrm{HDL}<1.03 / 1.3 \mathrm{mmol} / \mathrm{L}$ $(\mathrm{M} / \mathrm{F})$; systolic blood pressure $\geq 130 \mathrm{mmHg}$ and / or diastolic blood pressure $\geq 85 \mathrm{mmHg}$ or an antihypertensive therapy; fasting blood glucose values greater than $5.6 \mathrm{mmol} / \mathrm{L}$ or the use of glucose lowering treatment (11). Parameters according to which the diagnosis was set had been determined in the following way:

Venous blood samples were collected for the biochemical measurements after 48 hours of hospitalization. Serum glucose, HDL cholesterol, triglycerides, LDL cholesterol, total cholesterol and C-reactive protein (CRP) were measured with standard enzymatic colorimetric techniques.

Systolic and diastolic blood pressure was measured with aneroid sphygmomanometer in a sitting position and the average of three consecutive measurements at five minutes intervals was used as final values.

Body weight was measured on a calibrated electronic scale, and height was measured using a stan- dard wall-mounted stadiometer. Body mass index (BMI) was calculated as body weight in kilograms divided by height in squared meters $\left(\mathrm{kg} / \mathrm{m}^{2}\right)$.

Waist circumferences were obtained using a flexible steel metric tape according to standard procedures. Male patients with waist circumferences more the $102 \mathrm{~cm}$ and female more than $88 \mathrm{~cm}$ were considered to be obese. All anthropometric variables were measured by the same trained physician, during the hospitalization after the stabilization of vital parameters.

\section{Follow up}

During the 3 year follow up period, the authors collected data on mortality, cardiovascular mortality, new myocardial infarction, new revascularization (CABG and PCI), stroke and appearance of heart failure. For patients who died during the follow up, hospital records and necrophy data were reviewed. At the end of 36 month follow up, all alive patient were called for the final examination in order to fill in the questionnaire, the Short Form 36 (SF-36).

\section{Health status}

Since we wanted to determine the influence of MetS on HRQoL among the patients with STEMI, we chose to use generic questionnaire, the Short form 36 (SF-36). The reliability, validity and responsiveness of the SF-36 is well documented in patients with coronary artery disease (12). The SF-36 assesses eight health status domains: physical functioning, role physical functioning, role emotional functioning, mental health, vitality, social functioning, bodily pain and general health. Scale scores are obtained by summing the items together within a domain, dividing this outcome by the range of scores and then transforming the raw scores to a scale of 0 to 100 (13). A higher score on the SF-36 sub domains represents a better functioning; a high score on the bodily pain scale indicates freedom from pain. Based on the eight sub domains, physical and mental component summary scores can be calculated according to an algorithm, with the sub domains physical functioning, role physical functioning, bodily pain and general health being the primary contributors to the physical component score and role emotional functioning, vitality, social functioning, and mental health being the primary contributors to the mental component score (14).

\section{Statistical analysis}

Statistical analysis was performed with the SPSS 18.0 statistical package. Continuous data were expressed as mean \pm SD and categorical data as percentage. Comparisons of prevalence between groups were made using the chi square test or Fisher's exact test (in case the expected value of the variable was $<5$ in at least one group). Mean comparisons were performed using Student's t test. Multivariate analysis model with adjustment for differences at 
baseline was used to determine the impact of MetS on HRQoL, and the individual impact of MetS components on HRQoL after 36 month after myocardial infarction. A p value $<0.05$ was considered statistically significant.

\section{Ethical considerations}

All studies on humans described in the present manuscript were carried out with the approval of the responsible ethics committee and in accordance with national law and the Helsinki Declaration of 1975. (in its current revised form.) Informed consent was obtained from all patients included in the study.

\section{Results}

After diagnosing MetS, we formed a group of 217 patients with MetS (Mets+) and another group of 290 patients without the presence of Mets (MetS $(-))$. Patients with MetS were older, more likely to be women and had a significant prevalence of MetS components. Among the patients with MetS, the most frequent risk factor was hypertension followed by high triglycerides, abnormal fasting glucose level, obesity and low HDL.

In the group of patients without MetS the most frequent risk factor for CVD was smoking, whose presence was significantly higher in this group. In patients with MetS the presence of previous infarction, stroke, PCI and CABG were recorded in a higher percentage but without significant statistical difference (Table 1 ).

Parameters obtained during hospitalization are shown in Table 2. The parameters according to which the MetS was diagnosed were significantly higher in the group of patients with MetS with the exception of $\mathrm{HDL}$, which was significantly lower in the group of patients with MetS. It can also be observed that marker of inflammation (C-reactive protein) was increased in the group of patients with MetS. Between the examined groups, there was no significant difference in ejection fraction of the left ventricle, as well as extensity of coronary artery disease and localization of infarct-related artery.

The appearance of new adverse events during the three-year follow-up is shown in Table 3. At the end of the follow-up, among the examined groups, a significantly higher percentage of new myocardial infarction was recorded ( $p=0.004)$; and new, unexpected revascularization ( $p=0.014$ ). Patients with MetS had a higher percentage of all cause of death, cardiovascular death and strokes but without significant statistical difference. In patients with MetS there was significantly greater percentage of the recorded cases of hospitalization because of heart failure $(p=0.050)$. Figure 1 shows the mean scale SF36 in the examined groups. It can be noticed that the middle value scale SF- 36 is significantly lower in the group of patients with metabolic syndrome in all domains.

The results of multivariate logistic regression that we used to examine the impact of MetS on the quality of life, as well as individual influence of MetS components on the quality of life are shown in Tables 4 and 5 . The presence of MetS carried a significant risk for low HRQoL; it especially referred to physical components. Among mental components, MetS was a predictor of lower scores of vitality and mental health (Table 4). In the second multivariate model, we analyzed the individual influence of MetS components adjusted for sex, age and smoking. Multivariate logistic regression showed that only elevated blood pressure adversely affected physical functioning, general health and physical component score. Other MetS components individually did not carry a significant risk for low HRQoL (Table 5). There was no association between smoking and HRQoL in both models.

Table 1. Baseline characteristics of analyzed patients

\begin{tabular}{|c|c|c|c|}
\hline & $\begin{array}{c}\text { MetS (+) } \\
(N=217)\end{array}$ & $\begin{array}{c}\text { MetS (-) } \\
(N=290)\end{array}$ & $\mathbf{p}$ \\
\hline Female sex $n$ & $59(27.19 \%)$ & $54(18.62 \%)$ & 0.022 \\
\hline Age, years ( \pm SD) & $60.71 \pm 11.52$ & $57.50 \pm 10.95$ & 0.002 \\
\hline FBG $\geq 5.6 \mathrm{mmol} / \mathrm{L}$ or th & $158(72.81 \%)$ & $77(26.55 \%)$ & $<0.001$ \\
\hline $\mathrm{TG} \geq 1.7 \mathrm{~mol} / \mathrm{L}$ or th & $126(58.06 \%)$ & $103(35.52 \%)$ & $<0.001$ \\
\hline $\mathrm{HDL}<1.03 / 1.3 \mathrm{~mol} / \mathrm{I}(\mathrm{M} / \mathrm{F})$ or th & $114(52.53 \%)$ & $116(40.00 \%)$ & 0.005 \\
\hline $\mathrm{BP}>130 / 85$ or th & $173(79.72 \%)$ & $156(53.79 \%)$ & $<0.001$ \\
\hline Obesity* $^{*}$ & $136(62.67 \%)$ & $56(19.31 \%)$ & $<0.001$ \\
\hline Family history of CAD & $103(47.47 \%)$ & $126(43.44 \%)$ & 0.368 \\
\hline History of smoking & $144(66.36 \%)$ & $221(76.20 \%)$ & 0.015 \\
\hline Previous M.I. & $32(14.75 \%)$ & $31(10.68 \%)$ & 0.171 \\
\hline Previous stroke & $12(5.53 \%)$ & $11(3.79 \%)$ & 0.073 \\
\hline Previous PCI & $13(5.99 \%)$ & $9(3.10 \%)$ & 0.114 \\
\hline Previous CABG & $2(0.92 \%)$ & $1(0.34 \%)$ & 0.402 \\
\hline
\end{tabular}

FBG -fasting blood glucose; th- therapy; TG tryglicerides; BP- blood pressure *- waist circumference > $102 / 88 \mathrm{~cm}$ (M / F);

M.I. - myocardial infarction; CAD- coronary artery disease; PCI - Percutaneous coronary intervention; CABG-coronary arteries bypass surgery 
Table 2. Clinical characteristics of the analyzed patients

\begin{tabular}{|c|c|c|c|c|}
\hline & & $\begin{array}{c}\text { MetS (+) } \\
(N=217)\end{array}$ & $\begin{array}{c}\text { MetS (-) } \\
(N=290)\end{array}$ & $\mathbf{p}$ \\
\hline \multicolumn{2}{|c|}{ Systolic blood pressure $(\mathrm{mmHg})$} & $138.33 \pm 24.30$ & $129.15 \pm 21.31$ & $<0.001$ \\
\hline \multicolumn{2}{|c|}{ Diastolic blood pressure $(\mathrm{mmHg})$} & $88.01 \pm 12.88$ & $82.77 \pm 11.83$ & $<0.001$ \\
\hline \multicolumn{2}{|c|}{ Waist circumference $(\mathrm{cm})$} & $104.77 \pm 9.98$ & $95.01 \pm 14.06$ & 0.001 \\
\hline \multicolumn{2}{|c|}{ BMI $\left(\mathrm{kg} / \mathrm{m}^{2}\right)$} & $28.41 \pm 3.70$ & $25.61 \pm 3.60$ & $<0.001$ \\
\hline \multicolumn{2}{|c|}{ Glycemia (mmol/L) } & $7.46 \pm 2.31$ & $6.38 \pm 1.96$ & $<0.001$ \\
\hline \multicolumn{2}{|c|}{ HDL cholesterol (mmol/L) } & $1.07 \pm 0.25$ & $1.17 \pm 0.27$ & 0.001 \\
\hline \multicolumn{2}{|c|}{ Triglycerides (mmol/L) } & $2.20 \pm 1.09$ & $1.73 \pm 1.00$ & $<0.001$ \\
\hline \multicolumn{2}{|c|}{ LDL cholesterol (mmol/L) } & $3.57 \pm 1.06$ & $3.60 \pm 1.00$ & 0.180 \\
\hline \multicolumn{2}{|c|}{ Total cholesterol $(\mathrm{mmol} / \mathrm{L})$} & $5.50 \pm 1.30$ & $5.69 \pm 1.24$ & 0.594 \\
\hline \multicolumn{2}{|c|}{$\mathrm{C}$ - reactive protein $(\mathrm{mg} / \mathrm{L})$} & $5.10 \pm 2.02$ & $4.60 \pm 1.96$ & $<0.001$ \\
\hline \multicolumn{2}{|c|}{$\operatorname{LVEF}(\%)$} & $49.67 \pm 9.55$ & $49.51 \pm 10.14$ & 0.865 \\
\hline \multirow{3}{*}{$\begin{array}{l}\text { Localization } \\
\text { of M.I. }\end{array}$} & Anterior & $87(40.09 \%)$ & $133(45.86 \%)$ & \multirow{3}{*}{0.163} \\
\hline & Inferior & $125(57.60 \%)$ & $148(51.03 \%)$ & \\
\hline & Other & $5(2.30 \%)$ & $9(3.10 \%)$ & \\
\hline \multirow{3}{*}{ Infarct vessel } & LAD & $88(40.55 \%)$ & $134(46.21 \%)$ & \multirow{3}{*}{0.148} \\
\hline & $\mathrm{CX}$ & $34(15.67 \%)$ & $47(16.21 \%)$ & \\
\hline & $\mathrm{RCA}$ & $95(43.78 \%)$ & $109(37.59 \%)$ & \\
\hline \multicolumn{2}{|c|}{ One vessel disease } & $65(29.95 \%)$ & $113(38.97 \%)$ & \multirow{3}{*}{0.089} \\
\hline \multicolumn{2}{|c|}{ Two vessel disease } & $69(31.80 \%)$ & $90(31.03 \%)$ & \\
\hline \multicolumn{2}{|c|}{ Three vessel disease } & $83(38.25 \%)$ & $87(30.00 \%)$ & \\
\hline
\end{tabular}

LVEF - left ventricular ejection fraction; EDD - end diastolic diameter; ESD - end systolic diameter; M.I. - myocardial infarction; LAD - left anterior descending artery; CX - circumflex artery; $\mathrm{RCA}$ - right coronary artery

Table 3. Adverse outcomes during the 36-th month follow up

\begin{tabular}{||l|c||c||c||}
\cline { 2 - 4 } \multicolumn{1}{c|}{} & $\begin{array}{c}\text { MetS (+) } \\
\mathbf{n}(\%)\end{array}$ & $\begin{array}{c}\text { MetS (-) } \\
\mathbf{n}(\%)\end{array}$ & p \\
\hline All cause of death & $35(16.35)$ & $38(13.10)$ & 0.336 \\
\hline Cardiovascular death & $30(13.82)$ & $34(11.72)$ & 0.480 \\
\hline New myocardial infarction & $17(7.83)$ & $7(2.41)$ & 0.004 \\
\hline New stroke & $6(3.22)$ & $2(0.69)$ & 0.055 \\
\hline $\begin{array}{l}\text { New unexpected revascularization } \\
\text { (PCI/CABG) }\end{array}$ & $33(15.20)$ & $24(8.28)$ & 0.014 \\
\hline Dyspnea & $35(16.13 \%)$ & $28(9.66 \%)$ & 0.028 \\
\hline $\begin{array}{l}\text { Hospitalization due to heart } \\
\text { failure }\end{array}$ & $9(4.15)$ & $4(1.38)$ & 0.050 \\
\hline
\end{tabular}

PCI- percutaneous coronary intervention; CABG-coronary artery bypass surgery

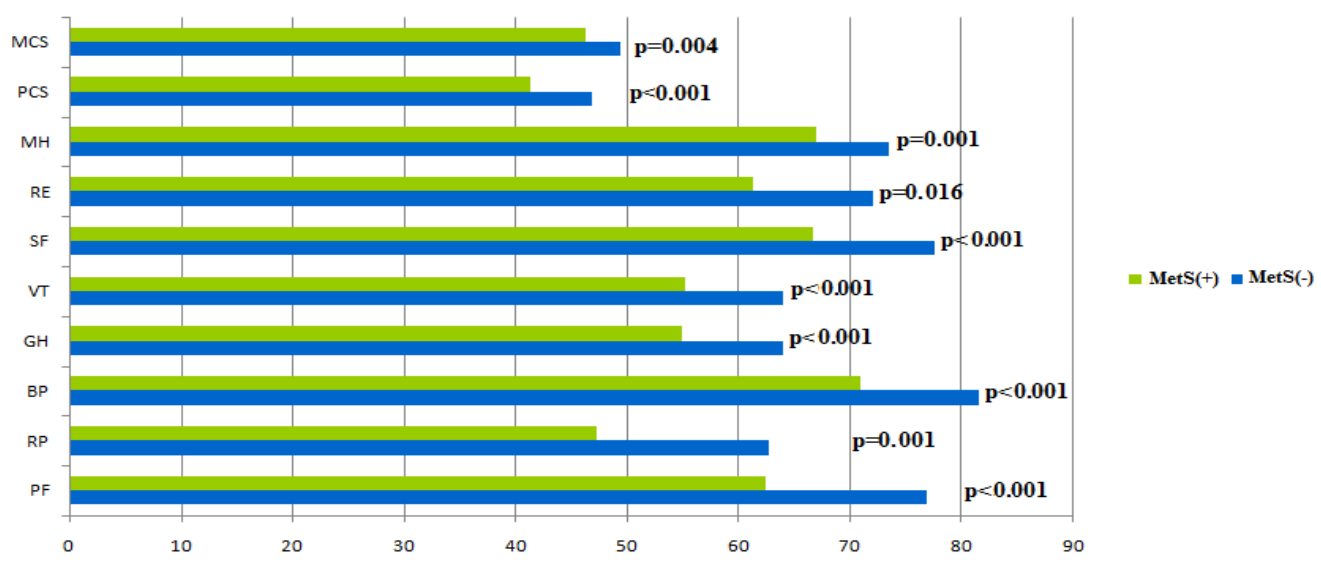

Figure 1. Mean scores (SD) for SF-36 subscales in examined patients at the end the follow-up: mental component summary (MCS); physical component summary (PCS); mental health (MH); role emotional functioning (RE); social functioning (SF); vitality (VT); general health (GH); bodily pain (BP); role physical functioning (RP) and physical functioning (PF) 
Table 4. Influence of MetS on HRQoL in multivariate logistic model adjusted for age, sex and smoking

\begin{tabular}{|c|c|c|c|c|}
\hline & & & \multirow{3}{*}{$\begin{array}{c}\mathbf{9 5 \%} \% \mathbf{C I} \\
1.572-4.581\end{array}$} & \multirow{3}{*}{$\frac{\mathbf{p}}{<0.001}$} \\
\hline & & \multirow{2}{*}{$\begin{array}{l}\text { OR } \\
2.684\end{array}$} & & \\
\hline \multirow{3}{*}{ PF } & $\begin{array}{l}\text { Metabolic } \\
\text { syndrome }\end{array}$ & & & \\
\hline & Gender & 1.821 & $1.010-3.320$ & 0.050 \\
\hline & Age & 1.051 & $1.021-1.081$ & 0.001 \\
\hline \multirow{2}{*}{ RP } & $\begin{array}{l}\text { Metabolic } \\
\text { syndrome }\end{array}$ & 2.121 & $1.374-3.274$ & 0.001 \\
\hline & Age & 1.022 & $1.000-1.044$ & 0.050 \\
\hline BP & $\begin{array}{l}\text { Metabolic } \\
\text { syndrome }\end{array}$ & 2.559 & $1.318-4.966$ & 0.005 \\
\hline GH & $\begin{array}{l}\text { Metabolic } \\
\text { syndrome }\end{array}$ & 2.522 & $1.318-4.966$ & $<0.001$ \\
\hline \multirow[t]{2}{*}{ PCS } & $\begin{array}{l}\text { Metabolic } \\
\text { syndrome }\end{array}$ & 2.516 & $1.557-4.065$ & $<0.001$ \\
\hline & & 1.029 & $1.006-1.052$ & 0.012 \\
\hline \multirow[t]{2}{*}{ VT } & $\begin{array}{l}\text { Metabolic } \\
\text { syndrome }\end{array}$ & 1.999 & $1.284-3.113$ & 0.002 \\
\hline & Gender & 1.687 & $1.093-2.866$ & 0.043 \\
\hline SF & - & - & - & - \\
\hline RE & Age & 1.021 & $1.008-1.044$ & 0.048 \\
\hline MH & $\begin{array}{l}\text { Metabolic } \\
\text { syndrome }\end{array}$ & 1.766 & $1.121-2.782$ & 0.016 \\
\hline MCS & Gender & 1.955 & $1.133-3.373$ & 0.016 \\
\hline
\end{tabular}

Physical functioning (PF); role physical functioning (RP); bodily pain (BP); general health (GH); physical component summary (PCS); vitality (VT); social functioning (SF); role emotional functioning (RE); mental health (MH) and mental component summary (MCS).

Table 5. Individual influence of MetS components (elevated blood pressure, abnormal fasting glucose level, obesity, elevated triglycerides, low HDL (according to the criteria for MetS)) on HRQoL in multivariate logistic model adjusted for age, sex and smoking

\begin{tabular}{|c|c|c|c|c|}
\hline & & OR & 95\%CI & $\mathbf{p}$ \\
\hline \multirow[t]{3}{*}{ PF } & Elevated blood pressure & 2.418 & $1.245-4.695$ & 0.009 \\
\hline & Gender & 2.306 & $1.220-4.358$ & 0.010 \\
\hline & Age & 1.047 & $1.016-1.078$ & 0.002 \\
\hline $\mathbf{R P}$ & - & - & - & - \\
\hline BP & - & - & - & - \\
\hline GH & Elevated blood pressure & 1.921 & $1.141-3.233$ & 0.014 \\
\hline \multirow[t]{2}{*}{ PCS } & Elevated blood pressure & 1.700 & $1.059-2.729$ & 0.028 \\
\hline & Gender & 2.040 & $1.093-3.805$ & 0.025 \\
\hline VT & Gender & 1.940 & $1.119-3.363$ & 0.018 \\
\hline SF & - & - & - & - \\
\hline $\mathbf{R E}$ & - & - & - & - \\
\hline MH & - & - & - & - \\
\hline MCS & Gender & 2.066 & $1.165-3.665$ & 0.013 \\
\hline
\end{tabular}

Physical functioning (PF); role physical functioning (RP); bodily pain (BP); general health (GH); physical component summary (PCS); vitality (VT); social functioning (SF);

role emotional functioning (RE); mental health $(\mathrm{MH})$ and mental component summary (MCS).

\section{Discussion}

MetS is a major cause of myocardial infarction, with a rapidly increasing tendency in prevalence (15). This claim was confirmed by the findings of several studies. Namely, Lee et al., Yilmaz et al. and Zeller et al. reported that the prevalence of MetS in patients with STEMI varied from $46 \%$ to $59,4 \%$ (1618 ). Also, a study originating from our region demonstrated a high prevalence of MetS among STEMI patients (19). Our study also confirmed a high prevalence of MetS in these patients; the incidence of MetS in our study was $42.80 \%$ which is in accordance with the above mentioned studies. Our study also revealed that female sex was more frequent among MetS patients. Similar to our findings are the findings of two studies that also found higher prevalence of females among MetS in patients with myocardial infarction $(18,19)$.

During the follow-up period, we found that among patients with MetS, there were a significantly higher number of myocardial infarctions and repeated revascularizations. These findings are in accordance with the results of Mente A. et al. and Takeno 
M. et al. $(20,21)$. Moreover, MetS is connected with the presence of pro-inflammatory condition that is confirmed by the increased presence of inflammatory markers suggesting an increased risk for new cardiovascular events $(22,23)$. Our study confirms that patients with MetS had significantly increased marker of inflammation (CRP) compared to the group of patients without MetS. In their study, Takeno $\mathrm{M}$. et al. showed that MetS was associated with high CRP level and that it was a significant predictor for the appearance of new cardiovascular events in patients who survived STEMI (21). All these claims suggest that MetS is significantly associated with the development of new coronary stenosis or restenosis during the follow-up period, which increase the need for new coronary revascularization (24) and the occurrence of heart failure (18). Our study confirmed these claims because patients with MetS have a significantly higher percentage of new revascularizations and the hospitalization due to heart failure.

It is well known that a myocardial infarction has a significant impact on HRQoL $(25,26)$, but little is known about what kind of impact MetS has on HRQoL among patients who survive STEMI. Several studies have shown the adverse impact of MetS on HRQoL. These are mainly studies that have investigated the general population (27). This is the first study that investigated the impact of MetS on HRQoL in a group of patients with STEMI. And we found that MetS was associated with lower HRQoL of the physical components of the SF-36. In addition, participants with MetS scored significantly lower on the PCS score than did persons without the syndrome. By contrast, no association was observed between MetS and the mental component summary score. Our results showed that MetS had an extremely adverse effect on the physical component of SF-36 and physical component score; but it had no impact on mental component score.

These findings can be explained by the fact that MetS can severely inhibit many of the normal physical functions that patient would have. Patients with MetS have increased subjective health complaints of musculoskeletal, neurological, and gastrointestinal pains. An impairment of circulation underlies all of these conditions, and results in pain with physical activity, promoting a sedentary lifestyle and a debilitating cycle ensues (28). In addition, MetS features like obesity and elevated blood pressure increase the work of the heart, while consistently increased insulin levels have macro and micro vascular complications inciting discomfort caused by decreased circulation. Thus, when these conditions are combined in MetS, the consequences can be assumed to be cumulative.

As we already mentioned, the individual components of MetS, such as obesity, elevated blood pressure and abnormal fasting plasma glucose have been shown in several studies to adversely affect the quality of life. Quovadis study, which included 1,822 obese patients, showed that patients with MetS have a poorer quality of life in physical terms, which is in accordance with our study. Individually, obesity, increased blood pressure and fasting plasma glucose had an extremely adverse effect on PCS and no impact on MCS (29). Interestingly, our results indicate that the individual MetS components except high blood pressure had no significant impact on HRQoL in study population. We found that increased blood pressure had a significant adverse impact on physical functioning, general health and physical component scores. These results coincide with the findings of individual studies $(30,31)$ which indicated that increased blood pressure adversely affected physical functioning. Also, our findings correlate with the findings of Chedraui et al. since they concluded that hypertension had an impact on the physical domains, while hyperglycemia was not found to have any major impact on the physical domain (32). These results may suggest that the metabolic syndrome represented to some degree the cumulative contributions of the individual components.

\section{Conclusion}

To our knowledge, the association between MetS and HRQOL has never been addressed among patients who survived STEMI. We conclude that patients with STEMI with MetS have significantly impaired HRQOL even after controlling for confounding variables. Our MetS subjects presented lower QOL in terms of physical health. These findings strongly suggest that HRQOL should be considered in the management of subjects with MetS.

\section{References}

1. Huang PL. A comprehensive definition for metabolic syndrome. Dis Model Mech 2009;2:231-7. [CrossRef][PubMed]

2. Kassi E, Pervanidou P, Kaltsas G, Chrosos G. Metabolic syndrome: definitions and controversis BMC MED 2011;9:48. [CrossRef][PubMed]
3. Allender S, Scarborough P, Peto V, Rayner M, Leal J, Luego-Fernandez $\mathrm{R}$ et al. European Cardiovascular Disease Statistics 2008.

4. Roger VL, Go AS, Lloyd-Jones DM, Berry JD, Borden WB, Bravata VM et al. Heart Disease and Stroke Statistics Update: A Report from the American Heart. Circulation, 2012. 
5. Oldridge N, Saner H, McGee HM. The Euro Cardio-QoL Project. An international study to develop a core heart disease health-related quality of life questionnaire, the HeartQoL. Eur J Cardiovasc Prev Rehabil 2005, 12(2): 87-94. [CrossRef][PubMed]

6. Swenson JR, Clinch JJ. Assessment of quality of life in patients with cardiac disease: the role of psychosomatic medicine. J Psychosom Res 2000, 48 (4-5): 405-15. [CrossRef] [PubMed]

7. Huang IC, Frangakis C, Wu AW. The relationship of excess body weight and health-related quality of life: evidence from a population study in Taiwan. Int J Obes (Lond) 2006, 30: 1250-9. [CrossRef] [PubMed]

8. Banegas JR, Lopez-Garcia E, Graciani A, GuallarCastillón $\mathrm{P}$, Gutierrez-Fisac JL, Alonso J et al. Relationship between obesity, hypertension and diabetes, and health-related quality of life among the elderly. Eur J Cardiovasc Prev Rehabil 2007, 14: 456-62. [CrossRef][PubMed]

9. Van de Werf F,Bax J,Betriu A,Blomstrom-Lundqvist $C$ Crea F,Falk V et al. Management of acute myocardial infarction in patients presenting with persistent ST-segment elevation: the Task Force on the Management of ST-Segment Elevation Acute Myocardial Infarction of the European Society of Cardiology. Eur Heart J 2008, 29: 2909-45. [CrossRef][PubMed]

10. Cheitlin MD, Armstrong WF, Aurigemma GP, Beller GA, Bierman FZ, Davis]. ACC/AHA/ASE Guideline Update for the clinical Application of Echocardiography: Summary article. Circulation, 2003, 108: 1146-62. [CrossRef][PubMed]

11. Grundy SM, Cleeman JI, Daniels SR, Karen AD, Robert $\mathrm{HE}$, Barry AF et al. American Heart Association; National Heart, Lung, and Blood Institute. Diagnosis and management of the metabolic syndrome: an American Heart Association/National Heart, Lung, and Blood Institute scientific statement. Circulation 2005, 112: 2735-2752. [CrossRef][PubMed]

12. Pettersen KI, Reikvam A, Rollag A, Tavem K . Understanding sex differences in health-related quality of life following myocardial infarction. International Journal of Cardiology 2008, 130 (3): 449-456. [CrossRef][PubMed]

13. Ware JE, Sherbourne CD. The MOS 36-item ShortForm Health Survey (SF-36). Med Care 1992, 30: 473-83. [CrossRef] [PubMed]

14. Ware JE, Kosinski M. Interpreting SF-36 summary health measures: a response. Qual Life Res 2001, 10: 405-13. [CrossRef][PubMed]

15. Ekmekci A, Gungor B, Uluganyan M, Ozcan KS, Bozbay $M$, Cicek $G$ et al. Impact of metabolic syndrome on future cardiovascular events in patients with first acute myocardial infarction. Coron Artery Dis 2009; 20: 370-5. [CrossRef][PubMed]

16. Lee MG, Jeong MH, Ahn Y, Chae SC, Hur SH, Hong TJ et al. Impact of the metabolic syndrome on the clinical outcome of patients with acute ST-elevation myocardial infarction. J Korean Med Sci 2010; 25:1456-61. [CrossRef][PubMed]

17. Yilmaz MB, Guray U, Guray $Y$, Altay H, Demirkan B, Caldir $V$ et al. Metabolic syndrome is associated with extension of coronary artery disease in patients with non-ST elevation acute coronary syndromes. Coronary Artery Dis 2005: 9:287-92.

18. Zeller M, Steg PG, RavisyJ, Laurent $Y$, Janin-Manificat $L$, L'Huillier I et al. Observatoire des Infarctus de Cote$\mathrm{d}$,Or Survey Working group. Prevalence and impact of metabolic syndrome on hospital outcomes in acute myocardial infarction. Arch Intern Med 2005; 165: 1192-8. [CrossRef] [PubMed]

19. Jelavic MM, Babic Z, Pintaric H. Metabolic syndrome: influence on clinical severity and prognosis in patients with acute ST-elevation myocardial infarction treated with primary percutaneous coronary intervention. Acta Cardiol. 2015; 70(2):149-56. [CrossRef][PubMed]

20. Mente A, Yusuf S, Islam S, McQueen MJ, Tanomsup S, Onen $C L$ et al. Metabolic Syndrome and Risk of Acute Myocardial Infarction. JACC 2010; 55(21): 2390-8 [CrossRef][PubMed]

21. Takeno M, Yasuda S, Otsuka Y, Morii I, Kawamura A, Yanoet $\mathrm{K}$ et al. Impact of Metabolic Syndrome on the Long-Term Survival of Patients With Acute Myocardial Infarction Potential Association With C-Reactive Protein. Circ J, 2008, 72: 415-419. [CrossRef][PubMed]

22. De Pergola G, Pannacciulli N. Coagulatioin and fibrinolysis abnormalitiesin obesity. J Endocrinol Invest 2002; 25: 899-904. [CrossRef][PubMed]

23. Juhan-Vague $I$, Morange $P E$, Alessi MC. The insulin resistance syndrome:implications for thrombosis and cardiovascular disease. Pathophysiol Haemost Thromb, 2002; 32: 269-273. [CrossRef][PubMed]

24. Levantesi G, Macchia A, Marfisi R, Franzosi MG, Maggioni AP, Nicolosi GL et al. Metabolic syndrome and risk of cardiovascular events after myocardial infarction. J Am Coll Cardiol, 2005; 46: 277-283. [CrossRef][PubMed]

25. Bengtsson I, Hagman M, Währborg P, Wedel H. Lasting impact on health-related quality of life after a first myocardial infarction. International Journal of Cardiology, 2004; 97: 509-516. [CrossRef][PubMed]

26. Lewis EF, Li Y, Pfeffer MA, Solomon SD, Weinfurt KP, Velazquez EJ et al. Impact of cardiovascular events on change in quality of life and utilities in patients after myocardial infarction: a VALIANT study (valsartan in acute myocardial infarction). JACC Heart Fail, 2014; 2(2): 159-65. [CrossRef][PubMed]

27. Ford ES, Li C. Metabolic Syndrome and Health-Related Quality of Life among U.S. Adults Ann Epidemiol, 2008; 18: 165-171. [CrossRef][PubMed]

28. Hjellset VT, Ihlebæk CM, Bjørge B, EriksenHR, Høstmark AT. Health-Related Quality of Life, Subjective Health Complaints, Psychological Distress and Coping in Pakistani Immigrant Women With and Without the Metabolic Syndrome: The Innva Diab - DEPLAN Study on Pakistani Immigrant Women Living in Oslo, Norway. J Immigr Minor Health; 2010.

29. Corica F, Corsonello A, Apolone $G$ et al and the QUOVADIS study group. Metabolic syndrome, psychological status and quality of life in obesity: the QUOVADIS Study. International Journal of Obesity, 2008; 32: 185-191. [CrossRef][PubMed]

30. Lalonde L, O'Connor A, Joseph L, Grover SA. Canadian Collaborative Cardiac Assessment Group Health-related quality of life in cardiac patients with dyslipidemia and hypertension. Qual Life Res, 2004;13(4): 793804. [CrossRef][PubMed]

31. Bardage C, Isacson DG. Hypertension and healthrelated quality of life. An epidemiological study in Sweden. J Clin Epidemiol, 2001;54(2): 172-81. [CrossRef][PubMed]

32. Chedraui $P$, Hidalgo L, Chavez D, Morocho N, Alvarado M, Huc A. Quality of life among postmenopausal Ecuaorian women participating in a metabolic syndrome screening program. Maturitas. 2007;20;56(1):45-53. [PubMed] 


\title{
UTICAJ METABOLIČKOG SINDROMA NA KVALITET ŽIVOTA BOLESNIKA SA AKUTNIM INFARKTOM MIOKARDA SA ST SEGMENT ELEVACIJOM
}

\author{
Milan Lović1, Dragan Đorđević1,2, Ivan S. Tasić1,2 \\ ${ }^{1}$ Institut za prevenciju i rehabilitaciju "Niška Banja", Srbija \\ ${ }^{2}$ Univerzitet u Nišu, Medicinski fakultet, Niš, Srbija \\ Kontakt: Milan Lović \\ Srpskih junaka 7, 18205 Niška Banja, Srbija \\ E-mail: milan.lovic@gmail.com
}

Metabolički sindrom (MetS) je skup više faktora rizika koji ukazuju na lošu prognozu nakon infarkta miokarda sa elevacijom ST segmenta (STEMI). Cilj ovog istraživanja bio je da se utvrditi uticaj MetS na kvalitet života kod bolesnika sa STEMI.

Ova prospektivna studija je sprovedena među STEMI bolesnicima koji su lečeni primarnom perkutanom koronarnom intervencijom u Kliničkom centru Srbije. Tokom tri godine, praćena je pojava novih velikih kardiovaskularnih događaja. Nakon 36 meseci prikupljeni su podaci za 507 bolesnika. Na kraju paćenja svi živi i sposobni bolesnici pozvani su kako bi popunili upitnik 36 (SF-36).

Prevalencija MetS je bila 42,80\%. Tokom praćenja je zabeležen povećan broj novih infarkta miokarda $(p=0,004)$, novih neplaniranih revaskularizacija $(p=0,014)$ i povećan broj hospitalizacija zbog srčane isuficijencije $(p=0,050)$ u grupi bolesnika sa MetS. Višestruka logistička regresijska analiza je pokazala da je MetS prediktor za lošije vrednosti: fizičkog funkcionisanja (OR 2,684; $p<0,001$ ), fizičku ulogu (OR 2,121; $p=0,001$ ), telesnu bol (OR 2,559; $p=0,005)$, opšte zdravlje (OR 2,522; $p<0,001$ ) i skor fizičkih komponenti (OR $2,516 ; p<0,001)$. Među komponentama koje utiču na mentalni status, Mets je prediktor lošije vitalnosti (OR 1,999; $p=0,002$ ) i mentalnog zdravlja (OR 2,142; $p=0,016)$.

Bolesnici sa Mets su u visokom riziku za pojavu novih kardiovaskularnih događaja, a prisutnost ovog sindroma povezana je s lošijim kvalitetom života onih koji su preživeli STEMI.

Acta Medica Medianae 2018;57(4):71-78.

Ključne reči: metabolički sindrom; infarkt miokarda sa elevacijom ST segmenta; kvaliteta života; novi kardiovaskularni događaj 